\title{
Growth rate, food intake and body composition before and after weaning in strains of mice selected for mature body-weight
}

\author{
By MARGARET W. STANIER AND L. E. MOUNT \\ Agricultural Research Council Institute of Animal Physiology, \\ Babraham, Cambridge $C B 2{ }_{4} A T$
}

(Received 30 September I971 - Accepted 14 February 1972)

\begin{abstract}
I. Litters of mice of strains selected for large and small mature body-weights ( $L$ and $S$ strains), together with litters of the randomly mated original stock (C), were studied both during suckling and for a further 2 months after weaning at 3 weeks old.

2. Suckled litters of $\mathbf{L}$ micc grew faster than $C$ and $S$ litters. The growth rate of $L$ and $C$ litters, but not that of $S$ litters, could be increased by reducing the size of the litter to four animals.

3. Cross-fostering experiments indicated no marked limitation on growth due to lack of maternal milk.

4. Between the $5^{\text {th }}$ and $25_{\text {th }}$ day after birth, when there were large differences in growth tate between the strains, there were no systematic differences in their body composition. Between the 2oth and $25^{\text {th }}$ day, during a phase of rapid growth, energy retained as fat-free tissue varied between the strains in the order $\mathrm{I}>\mathrm{C}>\mathrm{S}$, but energy retained as fat showed no inter-strain differences.

5. The voluntary food intake of the animals after weaning was reluted to body-weight and not to strain or sex, and there were no significant differences among the three strains either in body composition or in digestibility, whether food was offered on a restricted level or $a d l i b$.
\end{abstract}

Strains of mice of either less or greater than average body-weight at 6 weeks of age can be established by selection from randomly mated stock over a number of generations (Falconer, I960; Roberts, I966). At 6 weeks old a mouse is sexually maturc, and at this age an individual of the strain selected for large body-weight ( $\mathrm{L}$ mice) may weigh $30 \mathrm{~g}$, whereas one of the strain selected for small body-weight (S mice) may weigh only about $15 \mathrm{~g}$. The animals of the randomly mated original stock (C mice) at this age may weigh about $22 \mathrm{~g}$.

Some of the factors causing the difference in mature body-weight of mice may be apparent at birth or even before birth. Others may be revealed during suckling or after weaning. Mice were therefore observed from birth onwards to find: $(a)$ whether the weights of the young of different strains were significantly different even at birth; (b) how the growth rates during suckling and after weaning of the young of the two selected strains and the original stock were affected by litter size, litter number, milk supply of the mother and appetite of the young; $(c)$ whether differences occurred between the strains in body composition, or in the proportion of energy retained as fat or fat-free tissue, in the phase of rapid growth about the time of weaning; $(d)$ how spontaneous food intake, alimentary absorption and body composition varied after weaning; $(e)$ the effects on growth of restricting food intake. 
MATERIALS AND METHODS

\section{Animals and feeding arrangements}

Breeding pairs of mice which had been selected over seventeen generations for large and small 6-week body-weight ( $\mathrm{L}$ and $\mathrm{S}$ mice), together with breeding pairs of the original genetically-random stock ( $\mathrm{C}$ mice), were kindly supplied by the Institute of Animal Genetics, University of Edinburgh. The offspring of these breeding pairs, weaned at 3 weeks of age, were used for the experiments. All the experiments were carried out in a controlled-temperature room at $27^{\circ}$, with individual mice in separate plastic boxes measuring $270 \times 210 \times 100 \mathrm{~mm}$; a wire mesh of mesh size $12 \mathrm{~mm}$ covered the floor, and was supported about $3 \mathrm{~mm}$ above it, so that the animal did not become wet from urine or spilt water. The temperature of $27^{\circ}$ was chosen since it is below the critical temperature of $3^{\mathrm{I}-32^{\circ}}$ for the single mouse housed separately (Herrington, I940; Mount, 1971); consequently, the animals would not tend to become hyperthermic when active. On the other hand, $27^{\circ}$ is close enough to the zone of thermal neutrality for only a small thermoregulatory metabolic demand to be imposed on the animals. All animals were fed on Oxoid (Oxo Ltd) breeding diet in pellet form (gross energy, $4.34 \mathrm{kcal} / \mathrm{g}$ dry matter), whether on a restricted or ad lib. regimen. For restricted feeding, the weighed food was placed on the floor mesh, which was close enough to the floor to allow the mouse to eat all available particles. For $a d$ lib. feeding, food was placed in the usual hopper built into the wire-lid of the box.

\section{Birth weight, growth rate and lactation}

Litters of mice were weighed by placing the entire litter in a tared plastic container on the pan of a balance sensitive to $0.0 \mathrm{~g}$. The number of individuals in the litter was noted and the average weight was calculated. No attempt was made to identify or weigh individuals. The litters were weighed within $\mathrm{I} d$ of birth, and subsequently on 5 or $6 \mathrm{~d}$ each week until weaning on the 2oth day.

For recording growth rate during suckling, the $4^{\text {th }}$ day was taken as the starting point because the birth of the entire litter might be spread over $2 \mathrm{~d}$, and neonatal deaths were most frequent during this early period. By the $4^{\text {th }}$ day lactation was well established. After the I2th day, there was often a falling-off in growth rate, and later the young started to nibble at the solid food supplied to the parents. From the $4^{\text {th }}$ to the I2th day the average growth of a litter was effectively linear. So also was the growth rate for $10 \mathrm{~d}$ immediately after weaning. Growth rates were compared by fitting a straight line to the points of the weight-time graph by the method of least squares and computing the slope.

To find the effect of litter size on growth rate, some pairs of each strain, selected at random, raised a litter of 'quads'; that is, the litter was reduced to four animals selected at random, on the rst day after birth, immediately after the initial weighing. For the other breeding pairs the litter was allowed to maintain 'natural' size, whatever this might have been.

To investigate the role of milk supply and appetite the following procedure was used: a litter from $\mathrm{L}$ parents and a litter from $\mathrm{S}$ parents, born within $24 \mathrm{~h}$ of each other, were 
each reduced to four, and the young were exchanged, the progeny of $\mathrm{S}$ parents being fostered by the $\mathrm{L}$ mother and her own $\mathrm{L}$ young by the $\mathrm{S}$ mother. To encourage fostering, the newborn young were rolled in the nesting material of the foster-mother's cage before being placed in clean nesting material. The litter was weighed every day as described.

\section{Body composition}

Measurements were made of the water, fat, nitrogen, and ash in the carcasses of the three strains of mice $15^{-25} \mathrm{~d}$ old, the period of life at which the most rapid change in growth rate occurred. Young mice of each of the three strains were killed on the $\mathrm{r}_{5} \mathrm{th}$ day of life - that is, about $5 \mathrm{~d}$ before the normal time of weaning. Another group was killed on the 2oth day. Another group, weaned on the 2oth day, was killed on the $25^{\text {th }}$ day. The body composition of each individual in the twelve groups was measured. Most of the groups contained four individuals but a few contained only three or two individuals.

In a further experiment an assessment of the use of food for growth in the immediate postweaning period was made by the method of comparative slaughter. On the 2oth day after birth the litter under test was divided into two groups, the groups being as nearly as possible equal in number and weight. Each group of young mice was weighed. One group was killed and the combined carcasses of the entire group were analysed for water, fat and nitrogen. The other group was placed in a clean cage and was offered, for a $5 \mathrm{~d}$ period, enough food to provide each animal in the $\mathrm{L}$ and $\mathrm{C}$ litters with $20 \mathrm{~g}$, and each animal in the S litter with $16 \mathrm{~g}$. Water was provided $a d l i b$. and the mice were left undisturbed in a room kept at $22^{\circ}$ for $5 \mathrm{~d}$. After $5 \mathrm{~d}$, these weaned mice were weighed and killed and the carcasses of the entire group were analysed. The body composition of the weaned mice at $20 \mathrm{~d}$ was assumed to be the same as that of their litter-mates which were killed at $20 \mathrm{~d}$. On this assumption, the total energy in the bodies of the weaned group at the beginning and end of the $5 \mathrm{~d}$ period could be calculated. The food residues and excreta in the cage were separated and were each dried to constant weight. (No separate allowance was made for losses in urine.)

\section{Chemical methods}

The mouse was weighed immediately after death. It was placed on a tared Petri dish and its abdomen and skull were slit open to facilitate drying. To estimate water content, the carcass was dried to constant weight in an oven at $90^{\circ}$, a process which took 2-3 $\mathrm{d}$. The dried carcass was put into a dry Soxhlet thimble, $28 \times 80 \mathrm{~mm}$, and extracted into a tared flask with a mixture consisting of 2 parts chloroform and I part methanol, until the solvent was colourless. The bulk of the solvent was distilled off the liquid in the flask, which was then kept in an incubator at $34^{\circ}$ until it had reached constant weight. The weight of fat derived from the carcass was thus found, and checked by calculating the loss of weight for the material in the Soxhlet thimble after extraction. Total energy content was calculated as the sum of the weight of fat in $\mathrm{g} \times 8.47$ and the weight of the dry fat-free tissue in $\mathrm{g} \times 4^{\circ} 3 \mathrm{r}$. These factors had been arrived at by bomb calorimetry on samples of mouse fat and dry, defatted tissue. 
Table I. Expts 1-4. Animals used and measurements made on mice of strains selected or large $(L)$ or small $(S)$ mature body-zeight, and on control $(C)$ mice of the stock from which selection was originally made

\begin{tabular}{|c|c|c|c|c|c|}
\hline Expt no. & $\begin{array}{l}\text { Type of } \\
\text { mice }\end{array}$ & $\begin{array}{l}\text { No. of } \\
\text { mice }\end{array}$ & $\begin{array}{l}\text { Mean age } \\
\text { at beginning } \\
\quad(d)\end{array}$ & $\begin{array}{l}\text { Mean wt } \\
\text { at beginning } \\
\quad(\mathrm{g})\end{array}$ & $\begin{array}{l}\text { Duration } \\
\quad(d)\end{array}$ \\
\hline I : voluntary food intake & $\begin{array}{ll}\mathrm{L} & + \\
\mathrm{L} & 9 \\
\mathrm{C} & 0 \\
\mathrm{C} & 0 \\
\mathrm{~S} & 0 \\
\mathrm{~S} & 0\end{array}$ & $\begin{array}{r}9 \\
11 \\
12 \\
12 \\
10 \\
14\end{array}$ & $\begin{array}{l}30 \\
30 \\
28 \\
28 \\
27 \\
27\end{array}$ & $\begin{array}{l}26 \cdot 3 \\
23 \cdot 8 \\
21 \cdot 2 \\
19 \cdot 2 \\
15 \cdot 6 \\
12 \cdot 9\end{array}$ & $\begin{array}{l}20 \\
20 \\
15 \\
15 \\
14 \\
14\end{array}$ \\
\hline $\begin{array}{l}2: \text { body composition on } \\
\text { restricted food intake }\end{array}$ & $\begin{array}{l}\text { L } \\
\text { L } \\
\text { C } \\
\text { C } \\
\text { S } \\
\text { S } \\
\text { S }\end{array}$ & $\begin{array}{l}3 \\
5 \\
8 \\
8 \\
4 \\
4\end{array}$ & $\begin{array}{l}28 \\
28 \\
28 \\
28 \\
28 \\
28\end{array}$ & $\begin{array}{l}21 \cdot 0 \\
20 \cdot 3 \\
19 \cdot 0 \\
18 \cdot 0 \\
10 \cdot 8 \\
10.5\end{array}$ & $\begin{array}{l}62 \\
62 \\
62 \\
62 \\
62 \\
62\end{array}$ \\
\hline $\begin{array}{l}3: \text { digestible energy intake } \\
\text { and body composition on } \\
\text { restricted and voluntary } \\
\text { food intakes }\end{array}$ & $\begin{array}{ll}\mathrm{L} & 0 \\
\mathrm{~L} & 0 \\
\mathrm{C} & 0 \\
\mathrm{C} & 0 \\
\mathrm{~S} & 0 \\
\mathrm{~S} & 9\end{array}$ & $\begin{array}{l}4 \\
4 \\
6 \\
6 \\
4 \\
4\end{array}$ & $\begin{array}{l}28 \\
28 \\
28 \\
28 \\
28 \\
28\end{array}$ & $\begin{array}{r}11 \cdot 8 \\
13 \cdot 2 \\
10 \cdot 9 \\
11 \cdot 9 \\
8 \cdot 1 \\
8 \cdot 0\end{array}$ & $\begin{array}{l}65 \\
65 \\
65 \\
65 \\
65 \\
65\end{array}$ \\
\hline 4: comparative slaughter & 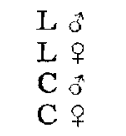 & $\begin{array}{l}9 \\
9 \\
9 \\
9\end{array}$ & $\begin{array}{l}28 \\
28 \\
28 \\
28\end{array}$ & $\begin{array}{l}26 \cdot 2 \\
24 \cdot 5 \\
16 \cdot 0 \\
16 \cdot 0\end{array}$ & $\begin{array}{l}80 \\
80 \\
90 \\
90\end{array}$ \\
\hline
\end{tabular}

The dried, defatted carcass was cut up with scissors and crushed to a powder in a mortar. Duplicate samples of this powder, about $0.2 \mathrm{~g}$ in weight, were incinerated with strong sulphuric acid, with mercuric chloride and selenium oxide as catalysts. Total nitrogen was estimated by the Kjeldahl method. Duplicate samples of the dry, defatted carcass, $0.3-0.5 \mathrm{~g}$, were taken into silica crucibles and heated overnight in a furnace at $700^{\circ}$. The ash was weighed. Energy contents of food and excreta dried to constant weight were obtained by bomb calorimetry (Gallenkamp adiabatic bomb calorimeter).

\section{Measurement of growth rate and food intake in weaned mice}

The measurements made in each of four experiments, together with the numbers, and range of age and of weight, of the mice used, are given in Table $\mathrm{I}$.

Expt I. Spontaneous food intake was measured for individual mice from the three strains between age limits of 26 and $52 \mathrm{~d}$. After 4 or $5 \mathrm{~d}$ habituation to the mouse-box with $a d$ lib. feeding, cach animal was weighed daily and offered cither 10 or $15 \mathrm{~g}$ food each day, depending on body-weight. The food which was left uneaten was collected and weighed at the end of each $24 \mathrm{~h}$ period, and the food intake was calculated from the difference between that offered and that left uneaten.

Expt 2. Observations on growth-rate and carcass composition after restricting food intake were made on thirty-two individual mice offered the same weight of food each day, beginning I week after weaning, at which time the animals werc about $28 \mathrm{~d}$ old. 
There were four groups of mice: eight $\mathrm{L}$ mice and eight $\mathrm{C}$ mice were offered $4 \mathrm{~g}$ food/d; eight more $\mathrm{C}$ mice and eight $\mathrm{S}$ mice were each offered $3.5 \mathrm{~g} / \mathrm{d}$. These amounts were selected as being somewhat below appetite. Thus, the $L$ and $S$ mice each had a control group having a daily food intake similar to their own. The animals were weighed on 5 or $6 \mathrm{~d}$ each week. As far as possible equal numbers of males and females were taken for each group; in the $\mathrm{L}$ group there were five females and three males.

Most of the mice were killed, by chloroform inhalation, on the 62nd day of observation, by which time they were nearly 3 months old, and the composition of the carcass (water, total lipid, nitrogen, ash) was determined.

Expt 3. Twenty-eight mice were used in another series of observations involving controllcd food intake. Four groups, each of four mice (two of each sex) were set up as for Expt 2. An additional three groups, one each of L, C and S, were set up at the same time, but allowed food ad lib. The animals were weighed daily as in Expt 2. The digestibility of the food was measured by collecting the faeces of each mouse for $3 \mathrm{~d}$ periods, weighing the dried material, and burning a sample of the dried faeces and also of the dried food in a bomb calorimeter (Gallenkamp adiabatic). This procedure was carried out for one $3 \mathrm{~d}$ period near the start of the experiment, for another in the middle, and for another at the end, shortly before the mice were killed on the 65 th day after restriction of food was begun. Separation of urine and faeces was not attempted but excreta were separated from food residues, which were also dricd and weighed. The composition of the carcass of each mouse was determined.

Expt 4. In this series of observations, confined to $\mathrm{L}$ and $\mathrm{C}$ mice, a total of eighteen $\mathrm{L}$ and eighteen $\mathrm{C}$ animals were given daily $4 \mathrm{~g}$ of food each, from $28 \mathrm{~d}$ old. Three or four mice of one sex from each litter were introduced into the experiment as the animals became available. Each animal was weighed three times a week. The bodyweight had reached a plateau after about 4 weeks in $\mathrm{L}$ mice and 7 weeks in $\mathrm{C}$ mice. The animals were then used to assess the energy requirement for growth and maintenance by the method of comparative slaughter. Three mice were killed over a period of $18 \mathrm{~d}$, one on day 0 , one on day 9 and the last on day 18 , and the bodies were analysed. Excreta of the last two mice were collected over the $9 \mathrm{~d}$ or $\mathrm{I} 8 \mathrm{~d}$ interval so that metabolizable energy intake could be measured.

\section{RESULTS}

\section{Birth weight and litter size}

Fig. I A shows the frequency of occurrence of mean birth weights in each of the genetic strains. There were no systematic differences between first, second and third litters of one breeding pair in respect of birth weight. The diagram shows that the offspring of the $\mathrm{L}$ strain were indeed on average somewhat heavier at birth than those of the $S$ strain, though there was an overlap of the range of birth weights and the difference was not significant.

Since the number of young competing for a limited milk supply might affect growth rate in early life, it was important to find whether a difference occurred between the strains in respect of normal litter size. Fig. I B shows the combined values recorded, 

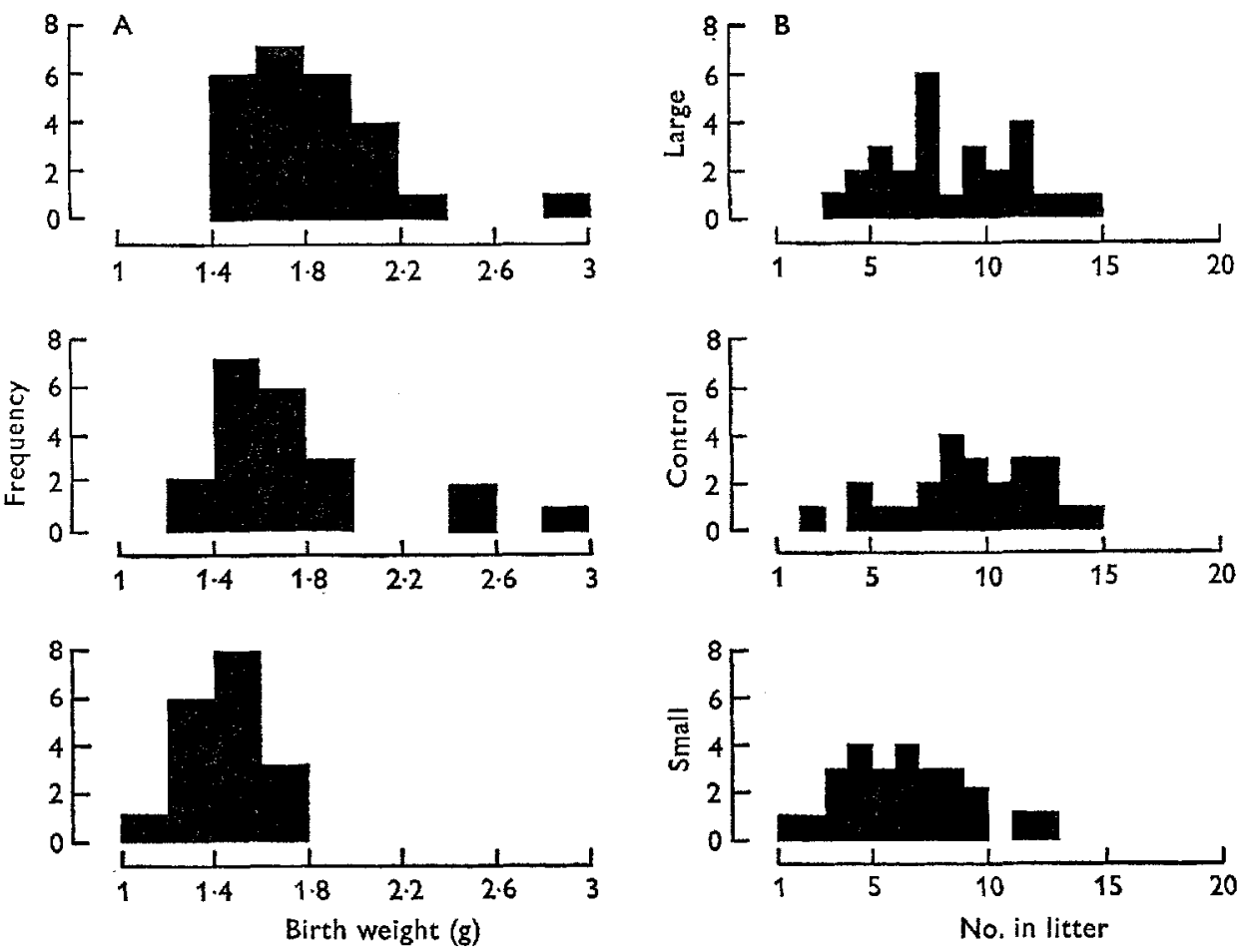

Fig, I. Frequency of occurrence, in three genetic strains of mice (large, control and small) (A) of a given birth weight in twenty-five litters of large, twenty-one of control and eighteen of small mice, and (B) of a given litter size of twenty-seven litters of large, twenty-four of control and twenty-six of small mice.

Table 2. Growth rates (mg/d) for three genetic strains (large, control and smail) of mice raised in litters either of natural size of in litters reduced to four pups

(A, litters of natural size, 4-12 d after birth; B, litters reduced to four pups, 4-12 d after birth; C, litters of natural size, $5 \mathrm{~d}$ before and after weaning; $\mathrm{D}$, litters reduced to four pups, $5 \mathrm{~d}$ before and after weaning. Mean values with their standard errors. Figures in parentheses give number of litters)
(A)
Large
Control
Small

$$
6 \mathrm{II} \pm 40(6)
$$
$409 \pm 24(6)$
I I
$399 \pm 19(8)$

Mean no. in

litter

(B)
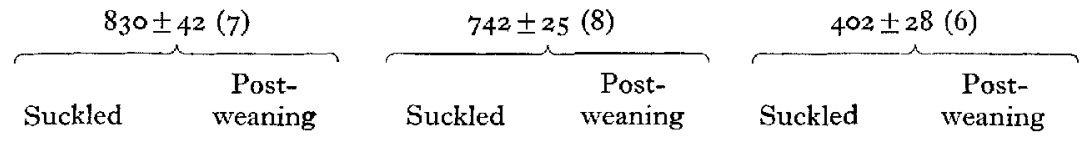

(C)

$$
611 \pm 39(6) \quad 1512 \pm 139(6)
$$

$400 \pm 28(5) \quad 8 \times 8 \pm 51(5)$

$\begin{array}{cc}390 \pm 20(7) & 686 \pm 100(7) \\ 8 & 8\end{array}$

litter

(D)

$$
830 \pm 49(6) \quad 1497 \pm 115(6) \quad 758 \pm 22(7) \quad 843 \pm 67(7) \quad 426 \pm 31(4) \quad 416 \pm 41(4)
$$


Vol. 28

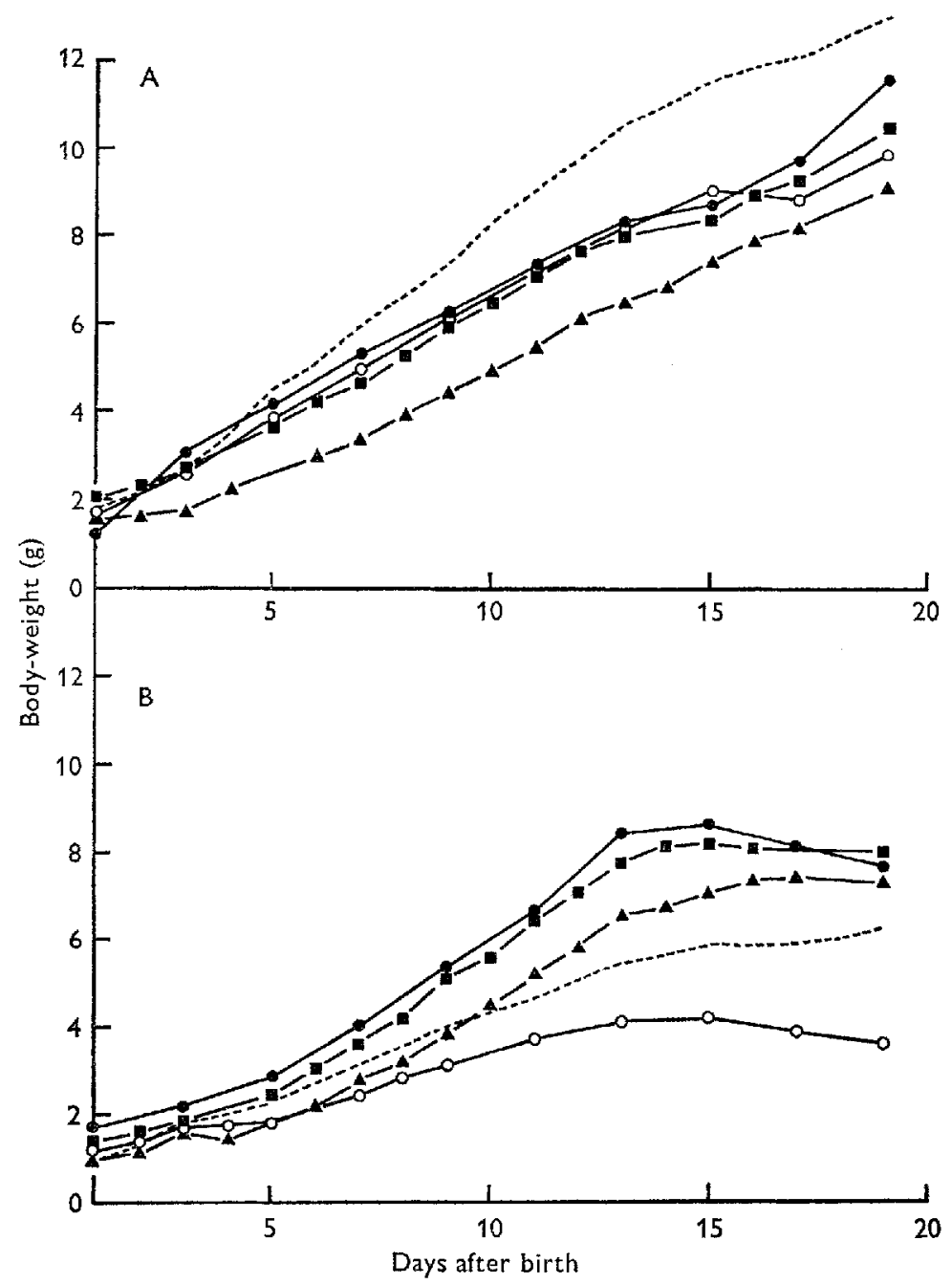

Fig. 2. Growth rate in three genetic strains of mice (large, control and small), of preweaning mice cross-fostered in litters of four. (A) Young of large dams fostered on to small dams; (B) young of small dams fostered on to large dams. Dotted lines show average normal growth rates; each set of symbols represents the growth rate of a different fostered litter.

for the $\mathrm{L}, \mathrm{C}$ and $\mathrm{S}$ litters, of the frequency of a given number of animals in the litter at birth. There is little evidence of difference between strains in respect of litter size at birth.

\section{Growth rate during suckling}

The growth rates of mice of the three strains, reared in groups of four or in groups of natural size, are given in Table 2. (Since there was no significant difference in growth rate between natural litters of four pups and those artificially reduced to four, both types of 'quads' have been included.) In litters of 'quads', the growth rate of suckled $\mathrm{L}$ mice, although larger, was not significantly different from that of $\mathrm{C}$ mice, but was 
highly significantly different $(P<0.00 \mathrm{r})$ from that of $\mathrm{S}$ mice. Growth rate of both $\mathrm{L}$ and $\mathrm{C}$ mice was significantly less in litters of natural size than in litters reduced to four $(P<0.05$ for $\mathrm{L}, P<0.00$ I for $\mathrm{C})$ but this reduction was proportionally less in $\mathrm{L}$ than in the controls. In litters of natural size, $\mathrm{C}$ and $\mathrm{S}$ mice during lactation grew significantly more slowly than $\mathrm{L}$ mice $(P<0 \cdot 00 \mathrm{r})$; this slow growth rate did not differ significantly whether the $S$ mice were reared as 'quads' or as litters of natural size.

Fig. 2 shows the growth rate of mice of 'quad' litters which had been exchanged at birth so that $\mathrm{L}$ mice were fostered by an $\mathrm{S}$ mother, and $\mathrm{S}$ mice by an $\mathrm{L}$ mother. The graph shows the weight of an average pup over the whole period of lactation, that is birth until $20 \mathrm{~d}$. The $\mathrm{L}$ young with an $\mathrm{S}$ foster-mother were able to grow rapidly (though not quite as rapidly as they would have grown as 'quads' with their own mother). This again pointed to the ability of the $S$ mother to respond to a greater demand (this is greater appetite of the young) by producing more milk. The $\mathrm{S}$ mice with an $\mathrm{L}$ foster-mother showed somewhat diverse responses. Some litters grew faster than they would have been expected to do with their own mother, others grew as slowly, or more slowly.

\section{Growth before and after weaning}

It has been observed that in both $\mathrm{L}$ and $\mathrm{C}$ mice a phase of rapid growth often occurs immediately after the time of weaning. Growth rates from the period of weaning $\pm 5 \mathrm{~d}$, for mice of all three strains reared both in litters of natural size and as 'quads', are shown in Table 2. During suckling, both $\mathrm{C}$ and S mice grew at a rate of about $0.4 \mathrm{~g} / \mathrm{d}$. All the $\mathrm{C}$ litters grew considerably faster at the postweaning stage, achieving a rate of about twice their rate during suckling. The $\mathrm{S}$ litters also showed increased growth, but not to the same degree as the $\mathrm{C}$ mice. The $\mathrm{L}$ litters (most of which already grew faster than $\mathrm{C}$ and $\mathrm{S}$ mice during suckling) all showed an increase in growth rate after weaning. One of them, indeed, grew nearly four times as fast at the postweaning stage as it did while suckling. When raised as 'quads', the $\mathrm{L}$ mice, even though their growth rate during suckling was already higher than that of natural litters, still managed to achieve a postweaning phase of rapid growth. The $\mathrm{C}$ mice also grcw faster as 'quads' at the suckling stage, but they hardly increased this growth rate after weaning and indeed even decreased it in some instances. The $\mathrm{S}$ litters reared as 'quads' grew no faster than those in litters of natural size and showed little postweaning change in growth rate. Once again the results showed the capacity of mice of the $L$ strain for extremely rapid growth just after weaning.

Body composition. To find whether the changes of body-weight of young mice in the preweaning period was true growth (that is increase in protein and mineral content), the bodies of the animals were analysed. Table 3 shows the percentage of fat and water in the bodies of mice killed at 15,20 and $25 \mathrm{~d}$ of age. Though there was considerable variation between individuals, there appeared to be little evidence of consistent differences between the genetic strains. As expected, any individual which contained an unusually large proportion of fat had an unusually low proportion of water. On the assumption that litter-mates had about the same body composition as each other at any given age, the percentage of fat in the body tended to fall between the 15 th and 
Table 3. Fat and water content (\% of dead weight) in three genetic strains (large, control and small) of mice at weaning and $5 d$ earlier and later

\begin{tabular}{|c|c|c|c|c|c|c|}
\hline \multirow[b]{2}{*}{ Litter of origin } & \multicolumn{3}{|c|}{ Fat } & \multicolumn{3}{|c|}{ Water } \\
\hline & $15 \mathrm{~d}$ & $20 \mathrm{~d}$ & $25 \mathrm{~d}$ & $15 \mathrm{~d}$ & $20 \mathrm{~d}$ & $25 \mathrm{~d}$ \\
\hline \multicolumn{7}{|l|}{ Large } \\
\hline I & $9 \cdot I$ & - & $9 \cdot 6$ & $73 \cdot 3$ & - & 710 \\
\hline 2 & $16 \cdot 4$ & $7 \cdot 7$ & $10 \cdot I$ & $70^{\circ} 9$ & $7 \mathrm{r} \cdot 9$ & $70 \cdot I$ \\
\hline 3 & IIIOO & $7 \cdot 8$ & $8 \cdot I$ & $6 x \cdot 6$ & $66 \cdot 2$ & 70.9 \\
\hline \multicolumn{7}{|l|}{ Control } \\
\hline I & $9 \cdot 3$ & $8 \cdot 0$ & - & $73 \cdot 7$ & $69 \cdot 8$ & - \\
\hline 2 & $8 \cdot 8$ & $\overline{0}$ & $7 \cdot 7$ & $72 \cdot 7$ & - & $72 \cdot 7$ \\
\hline 3 & - & 8.8 & - & 一 & $71 \cdot 7$ & - \\
\hline 4 & - & $9 \cdot 3$ & 6.9 & - & $70 \cdot 4$ & $71 \cdot 2$ \\
\hline 5 & $14 \cdot 2$ & - & 13.5 & 67.4 & - & $66 \cdot 4$ \\
\hline 6 & $7 \cdot 5$ & $9^{2}$ & $7 \cdot 7$ & $72 \cdot 2$ & $70 \cdot 7$ & $72 \cdot 7$ \\
\hline \multicolumn{7}{|l|}{ Small } \\
\hline I & 8.7 & 5.2 & $6 \cdot 2$ & 73.5 & $68 \cdot 7$ & $72 \cdot 3$ \\
\hline 2 & 8.0 & $8 \cdot 5$ & $7 \cdot 0$ & $70^{\circ} 0$ & $7{ }^{1} \cdot 9$ & $72 \cdot 4$ \\
\hline 3 & $20 \cdot 4$ & $18 \cdot 7$ & $13 \cdot 3$ & $62 \cdot 1$ & $61 \cdot 7$ & $67 \cdot 2$ \\
\hline 4 & $12 \cdot 7$ & $4^{\prime} 9$ & 10.2 & $69 \cdot 0$ & $72 \cdot 0$ & $67 \cdot 3$ \\
\hline Mean & II 4 & $8 \cdot 8$ & $9 \cdot \mathrm{I}$ & $69 \cdot 7$ & $69 \cdot 5$ & $70 \cdot 4$ \\
\hline
\end{tabular}

2oth day of life, a period in which the growth rate of young suckled mice declined. The ash varied between 1.9 and $4.1 \%$ of the fresh body-weight and the nitrogen between 2 and $4 \%$. There was no systematic variation with age or genetic strain. During the $5 \mathrm{~d}$ period immediately after weaning the retention of fat was very variable among individuals and showed no consistent difference with strain.

\section{Growth rate and food intake in weaned mice}

Expt $\mathrm{r}$. With ad lib. feeding the $\mathrm{L}$ mice tended to eat more, and the $\mathrm{S}$ mice less, than the controls. The results for males and females separately are given in Fig. 3, in which the voluntary food consumption is plotted against body-weight. The $\mathrm{S}$ mice were eating $3^{-4} \mathrm{~g}$ food/d, the $\mathrm{C}$ mice approximately $4-5 \mathrm{~g} / \mathrm{d}$, and the $\mathrm{L}$ mice about $4 \cdot 5-5 \cdot 5 \mathrm{~g} / \mathrm{d}$.

Expt 2. The growth curves of the animals are presented in Fig. 4, each point representing the mean weight on each day of animals of one sex. This experiment involved only restricted feeding. The $\mathrm{L}$ mice, already large at weaning, showed a much larger increment of body-weight than the controls. This was in spite of the fact that after the

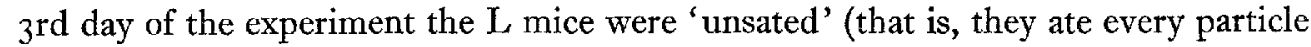
of the food offered) whereas the controls did not reach the point of being unsated until about the zoth day of the experiment. The $S$ mice and their controls presented a somewhat different picture. The $\mathbf{S}$ mice, smaller initially than the controls, were in effect sated throughout their life on the daily $3.5 \mathrm{~g}$ food ration. They grew faster than the controls, whose growth rate was effectively retarded. The graphs reveal that the $\mathrm{L}$ mice reached a plateau body-weight of about $27-28 \mathrm{~g}$ after about $30 \mathrm{~d}$ of restricted feeding; for the $\mathrm{C}$ mice it was about $22 \mathrm{~g}$ and for the $\mathrm{S}$ mice $\mathrm{I} 8 \mathrm{~g}$.

Expt 3. Both restricted and $a d$ lib. feeding were used in this experiment. Fig. 5 shows the growth curves for the restricted mice and Fig. 6 for mice fed ad lib. The 


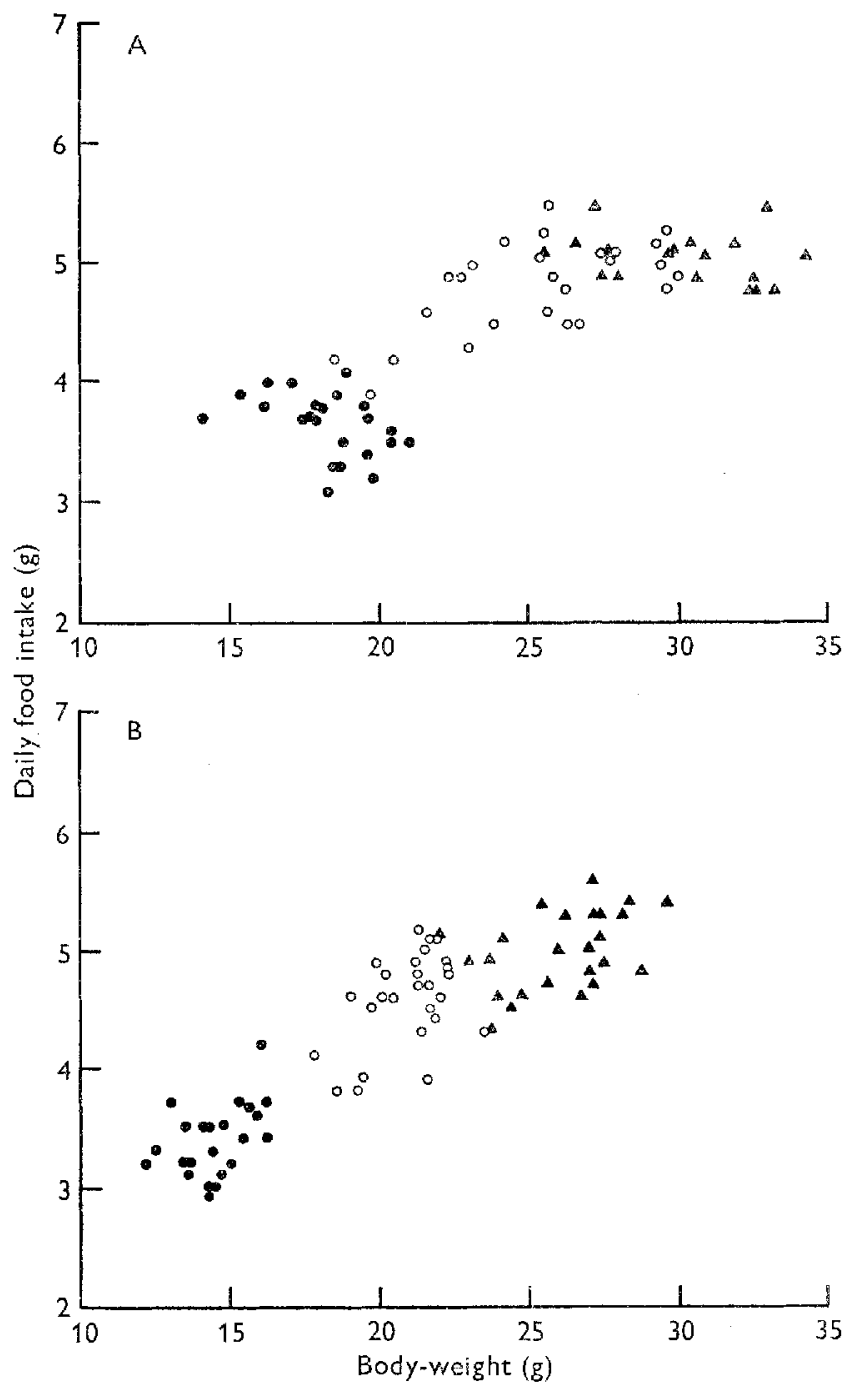

Fig. 3. Relation of voluntary food intake to body-weight in (A) male and (B) female mice of three genetic strains (large, control and small). $\Delta$, large; 0 , control; $\mathbf{O}$, small.

growth of the mice whose food intake was restricted followed a pattern similar to those of Expt 2, and the animals reached similar plateau weights after $30 \mathrm{~d}$ of restriction. Predictably, unrestricted food intake produced for both $\mathrm{L}$ and $\mathrm{C}$ mice a much higher growth rate than restriction to $4 \mathrm{~g}$ food. For S mice, however, restriction to $3.5 \mathrm{~g}$ daily had little effect on growth rate. Once again this daily ration sated the $\mathrm{S}$ mice.

Expt 4. This experiment involved only $\mathrm{L}$ and $\mathrm{C}$ mice, fed at the restricted level of $4 \mathrm{~g} / \mathrm{d}$. The growth curves are given in Fig. 7 . As in the previous results, the $\mathrm{L}$ mice achieved a plateau of about $27 \mathrm{~g}$ in body-weight after $30 \mathrm{~d}$ of restriction, whereas the $\mathrm{C}$ mice on the same ration achieved a plateau body-weight of about 2r g. A noteworthy difference from Figs. 4 and 5 is that the L mice happened to have already 
Vol. 28

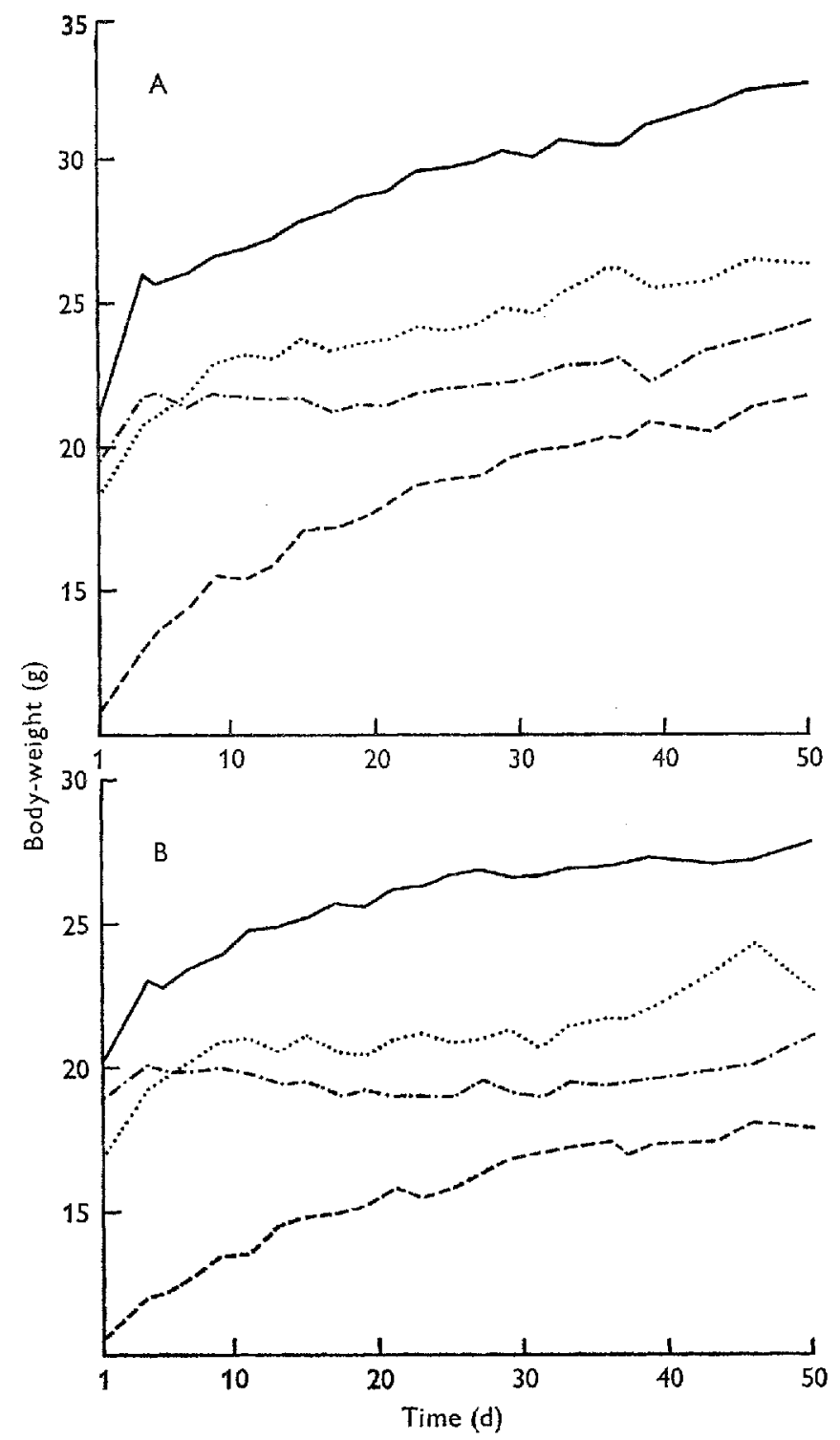

Fig. 4. Growth of (A) male and (B) female mice of three genetic strains (large, control and small) on restricted food intake. - - large on $4 \mathrm{~g} / \mathrm{d} ; \ldots . .$, , control on $4 \mathrm{~g} / \mathrm{d} ; \cdots-$, control on $3.5 \mathrm{~g} / \mathrm{d} ;----$, small on $3.5 \mathrm{~g} / \mathrm{d}$.

attained a much larger body-weight by the 28 th day of life, the start of the period of restriction, than they had in the first two experiments; they were in fact already close to the plateau weight which they were able to maintain on the daily $4 \mathrm{~g}$ ration.

Gross feed efficiency. This quantity was calculated as the ratio of daily weight change to daily food intake in nine $\mathrm{L}$, twelve $\mathrm{C}$ and ten $\mathrm{S}$ male mice fed $a d l i b$. for the period of days $5^{-12}$ after weaning. The mean values of gross efficiency were $0.240 \pm 0.023$ for the $\mathrm{L}$ mice, $0.204 \pm 0.020$ for the $\mathrm{C}$ mice and $0.144 \pm 0.020$ for the $\mathrm{S}$ mice. The values 


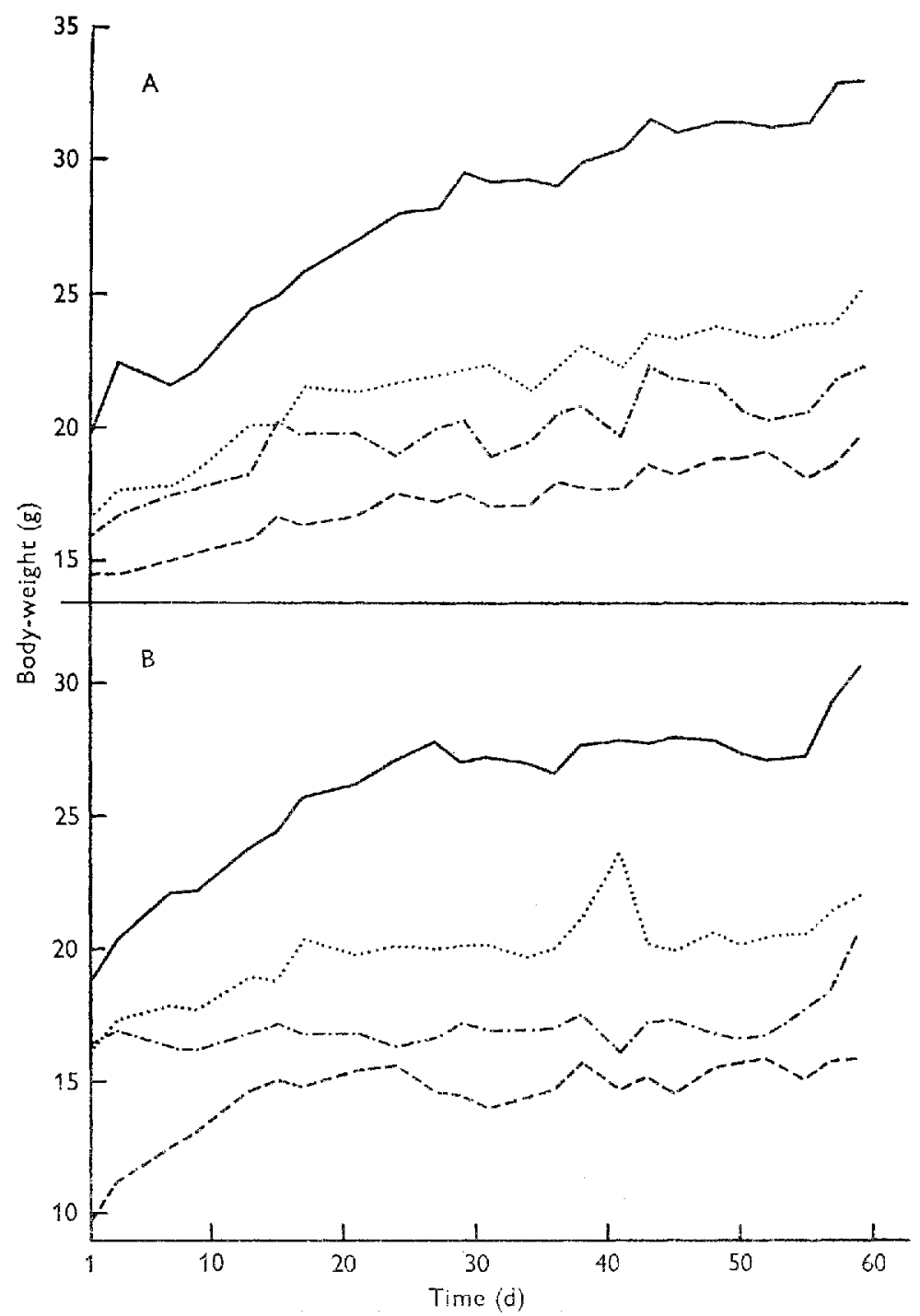

Fig. 5. Growth of (A) male and (B) female mice of three genetic strains (large, control and small) on restricted food intake. - , large on $4 \mathrm{~g} / \mathrm{d} ; \ldots . .$. , control on $4 \mathrm{~g} / \mathrm{d} ;-.-$. , control on $3.5 \mathrm{~g} / \mathrm{d}$; - - - small on $3.5 \mathrm{~g} / \mathrm{d}$.

for $\mathrm{L}$ and $\mathrm{C}$ mice were not significantly different, but those for the $\mathrm{S}$ mice were significantly smaller than those of either of the other strains $(P<0.05)$.

\section{Digestible food intake}

Since there were differences in gross feed efficiency between $\mathrm{L}, \mathrm{C}$ and $\mathrm{S}$ mice, particularly in early life, it was important to determine whether there were also differences between the strains in their ability to digest and absorb food. The digestibility of the food eaten was determined from the energy values of food and of excreta collected over $3 \mathrm{~d}$ periods at three stages of Expt 3 . The consistency of energy value of faeces 
Vol. 28

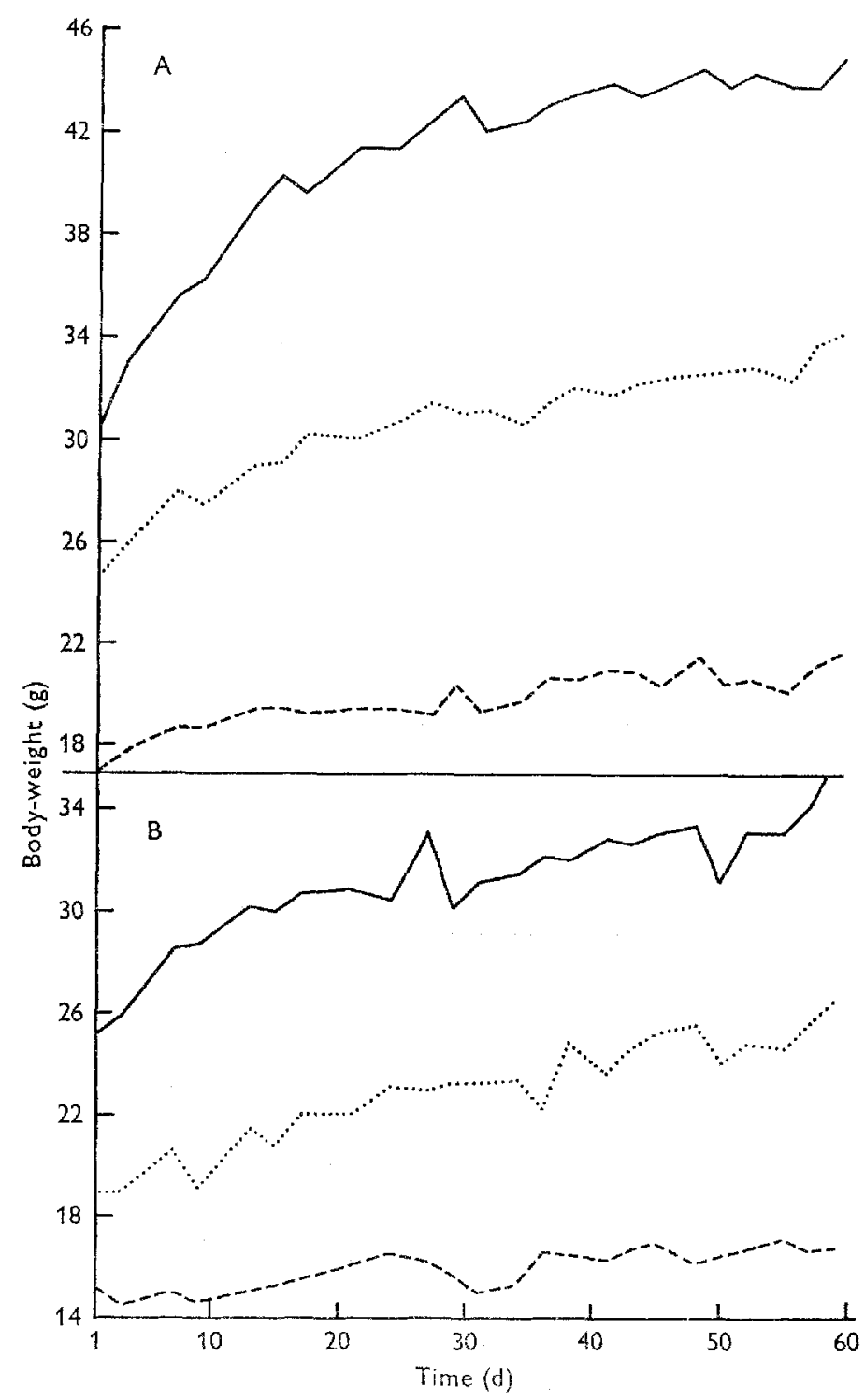

Fig. 6. Growth of $(A)$ male and $(B)$ female mice of three genetic strains (large, control and small) on ad lib. food intake. ——, large; , control; - - - - small.

collected from L, C and S mice, whether on restricted or ad lib. feeding, is apparent in Table 4. The values obtained for digestibility showed no evidence of systematic variation with genetic strain, or with restricted or ad lib. feeding regimen (Table 5). The general mean value for digestibility [( $\mathrm{kcal}$ absorbed $\div \mathrm{kcal}$ eaten $) \times \mathrm{I} 00]$ was $77 \cdot 6 \pm \mathrm{I} \cdot \mathrm{O}$ SE (eighty-four observations). Digestibility for adult $\mathrm{L}$ and $\mathrm{C}$ mice on restricted food intake was also measured over a $9 \mathrm{~d}$ or $18 \mathrm{~d}$ period in Expt 4 . Again, no significant difference between strains was detectable. For $\mathrm{L}$ mice digestibility was $73^{\cdot} \cdot \pm \pm \mathrm{I} \cdot 3 \mathrm{SE}$, for $\mathrm{C}$ mice, $74 \cdot 3 \pm 2 \cdot 3 \mathrm{SE}$. 


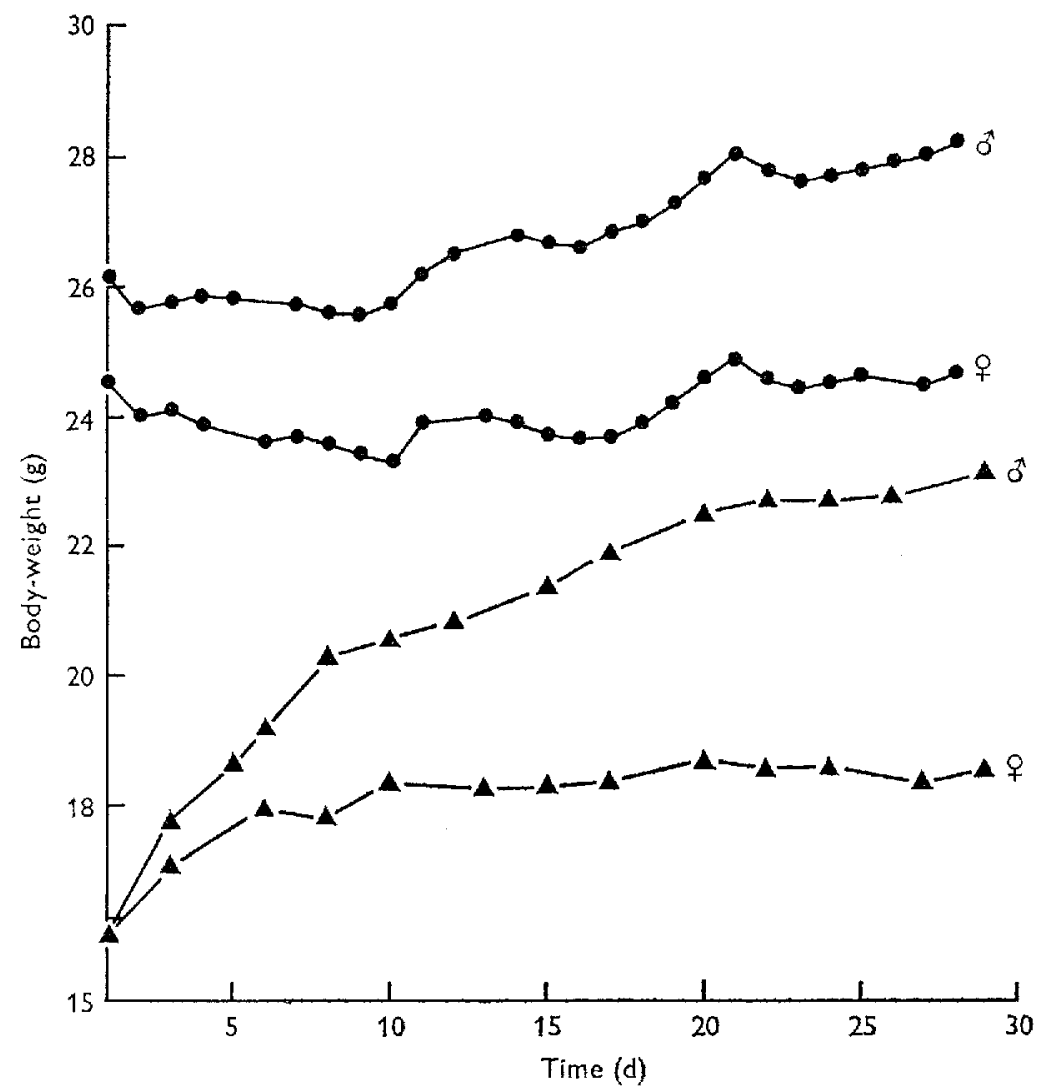

Fig. 7. Growth of two genetic strains of (large and control) mice on restricted food intake. All mice were offered $4 \mathrm{~g}$ food daily from $28 \mathrm{~d}$ after birth.

\section{Body composition}

The mean body composition of groups of mice of the three strains, from Expts 2 and 3 , slaughtered after constant restricted food intake, and also after feeding $a d$ lib., is set out in Table 6. A noteworthy feature is the consistency of results for all groups in all strains, in respect of body composition. The most undernourished animals (as assessed by the short time from the start of restriction in which they reached the 'unsated' state) were the $\mathrm{L}$ mice on $4 \mathrm{~g}$ and the $\mathrm{C}$ mice on $3.5 \mathrm{~g}$. The slightly lower mean percentage of fat in these two groups, compared with the corresponding $4 \mathrm{~g} \mathrm{C}$ mice and $3.5 \mathrm{~g} \mathrm{~S}$ mice, might reflect this undernutrition. As expected for undernourished animals, the unusually low-fat content of the $4 \mathrm{~g} \mathrm{~L}$ mice of Expt 2 was accompanied by unusually high water and ash contents.

\section{Energy of growth and maintenance}

The adult $\mathrm{L}$ and $\mathrm{C}$ mice of Expt 4 killed over an $\mathrm{I} 8 \mathrm{~d}$ period when a plateau of bodyweight had been reached had during this $18 \mathrm{~d}$ period a very consistent metabolizable energy intake, as between groups, strains and sexes, at $72-76 \%$ of the energy of food eaten; for the whole $18 \mathrm{~d}$ period the mean energy intake for $\mathrm{L}$ groups was $208 \pm 2 \cdot 5$ and 
Table 4. Energy value (kcalig and $k f / g$ ) of excreta of three genetic strains (large, control and small) of mice, measured in a $3 d$ collection period at intervals of 1 month. Some animals of each strain were on restricted food intake; others were fed ad lib.

(Mean values: standard errors are given only for values expressed in kcal/g.

Numbers of mice in parentheses)

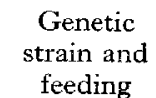

Genetic

feeding

Large

Ad lib. (4)

$\mathrm{kcal} / \mathrm{g}$

$\mathrm{kJ} / \mathrm{g}$

Restricted (4)

kcal/g

$\mathrm{kJ} / \mathrm{g}$

Control
Ad lib. (4)
$\mathrm{kcal} / \mathrm{g}$
$\mathrm{kJ} / \mathrm{g}$

$3 \cdot 75$

I $5 \cdot 69$

Restricted (8)

$\mathrm{kcal} / \mathrm{g}$

$\mathrm{kJ} / \mathrm{g}$

377

I 577

Small

Ad lib. (4)

kcal/g $\quad 3.99$

$\mathrm{kJ} / \mathrm{g}$

3.99
$16 \cdot 69$

Restricted (4)

$\mathrm{kcal} / \mathrm{g}$

$\mathrm{kJ} / \mathrm{g}$

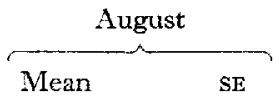

SE

0.02

$3 \cdot 82$

0.12

$3 \cdot 56$

0.07

0.03

$3 \cdot 52$

14.73

0.09

$3 \cdot 55$

I 4.85

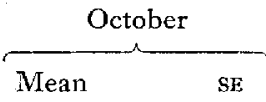

Table 5. Gross energy intake $(G E)$ and digestible energy $(D E)$ as a percentage of $G E$, in groups of four mice of three genetic strains (large, control and small) on restricted and ad lib. feeding for 3 d periods at intervals of $\mathrm{I}$ month. Some animals in each strain were on restricted food intake; others were fed ad lib.

\begin{tabular}{|c|c|c|c|c|c|c|}
\hline \multirow{2}{*}{$\begin{array}{l}\text { Genetic strain } \\
\text { and feeding }\end{array}$} & \multicolumn{2}{|c|}{ August } & \multicolumn{2}{|c|}{ September } & \multicolumn{2}{|c|}{ October } \\
\hline & GE & $\widehat{\mathrm{DE}}$ & GE & $\mathrm{DE}$ & $\mathrm{GE}$ & $\mathrm{DE}$ \\
\hline \multicolumn{7}{|l|}{ Large } \\
\hline Ad lib. & $55^{\circ} 6$ & $77 \cdot 6$ & 60.9 & $79 \cdot x$ & $60 \cdot 6$ & $79 \cdot 8$ \\
\hline Restricted, $4 \mathrm{~g}$ & 417 & $77 \cdot 1$ & $4 \pi \cdot 7$ & $78 \cdot 4$ & $41 \cdot 0$ & $78 \cdot 6$ \\
\hline \multicolumn{7}{|l|}{ Control } \\
\hline Ad lib. & $5 x \cdot 6$ & $75 \cdot 6$ & $65 \cdot 9$ & $78 \cdot 6$ & $56 \cdot 9$ & $79^{\circ} 9$ \\
\hline Restricted, $4 \mathrm{~g}$ & $4 I \cdot 5$ & $77 \cdot 2$ & $41 \cdot 7$ & $79 \cdot 5$ & $4 I \cdot 6$ & $77 \cdot 5$ \\
\hline Restricted, $3.5 \mathrm{~g}$ & $36 \cdot 6$ & $74^{\circ} 1$ & $36 \cdot 2$ & $78 \cdot 8$ & $36 \cdot 0$ & $8 I \cdot 7$ \\
\hline \multicolumn{7}{|l|}{ Small } \\
\hline Ad lib. & 44.5 & $82 \cdot 3$ & $39 \cdot 7$ & $78 \cdot 5$ & $4 I \cdot 2$ & $8 \mathrm{I} \cdot \mathrm{I}$ \\
\hline Restricted, $3.5 \mathrm{~g}$ & $3^{6 \cdot 5}$ & $75 \cdot 2$ & $3 \times 0$ & $75^{-8}$ & $35^{\circ} \mathrm{I}$ & $8 I \cdot 6$ \\
\hline
\end{tabular}




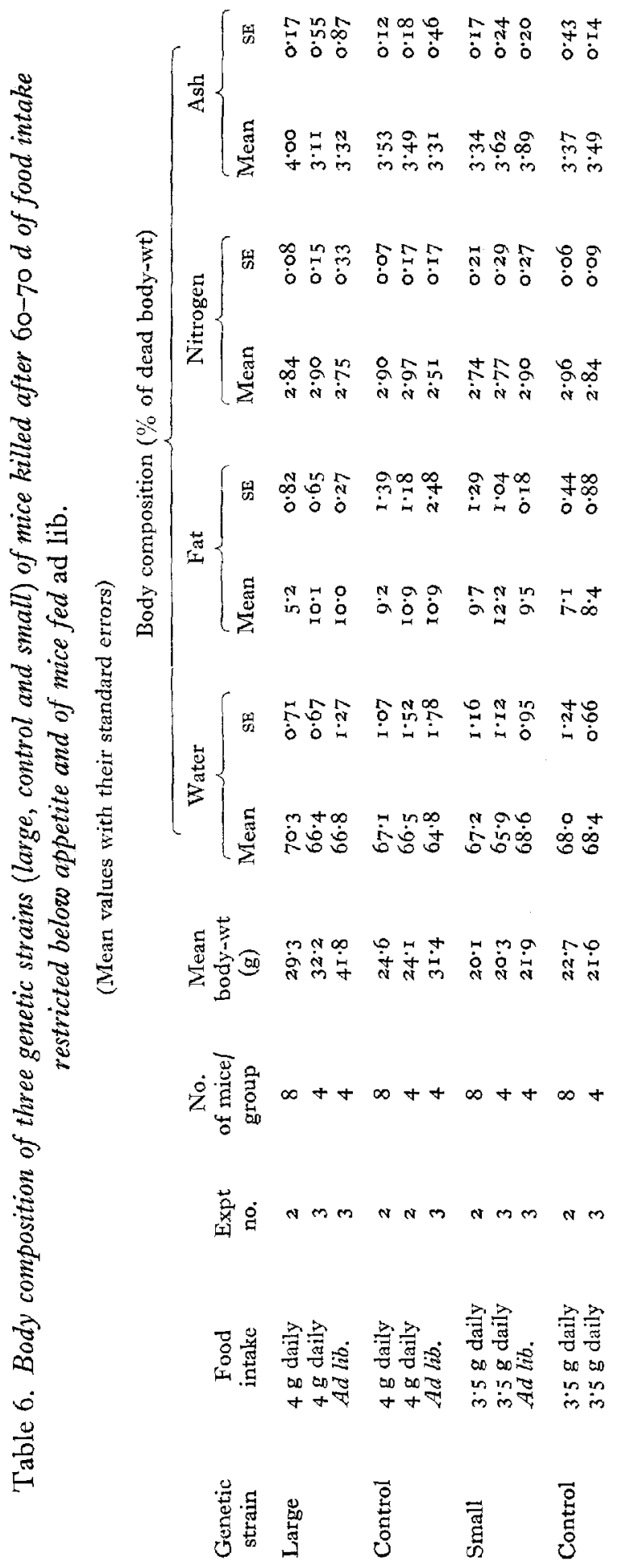


Table 7. Energy content (kcal and $k f$ ) of carcasses of mice of two genetic strains (large and control) killed on day o, day 9 and day $\mathrm{x} 8$ of the period of comparative slaughter. Mean values are also given in $k \mathcal{F}$

(Figures in parentheses show number of litters)

\begin{tabular}{|c|c|c|c|c|c|c|}
\hline \multirow[b]{2}{*}{ Genetic strain } & \multicolumn{3}{|c|}{ Male (3) } & \multicolumn{3}{|c|}{ Female (3) } \\
\hline & Day o & Day 9 & Day 18 & Day o & Day 9 & Day 18 \\
\hline \multirow[t]{3}{*}{ Large } & $6 x \cdot 2$ & $62 \cdot 3$ & $59 \cdot 5$ & $50 \cdot 5$ & $42 \cdot 5$ & $32 \cdot 7$ \\
\hline & 378 & $4 I \cdot I$ & $53 \cdot 9$ & $36 \cdot 3$ & $38 \cdot 6$ & $42 \cdot 0$ \\
\hline & $66 \cdot 0$ & $73 \cdot 8$ & $71 \cdot 6$ & $45^{\circ} 4$ & $36 \cdot 6$ & $36 \cdot 2$ \\
\hline \multirow[t]{3}{*}{ Mcan } & $55^{\circ} 0$ & $59^{\circ} \mathrm{I}$ & $6 x \cdot 7$ & $44^{\prime} I$ & $39 \cdot 2$ & $37 \cdot 0$ \\
\hline & $23 \times 10$ & $24 I \cdot 7$ & $258 \cdot 2$ & I 84.5 & $164 \cdot 0$ & $\mathrm{I}_{54} \cdot 8$ \\
\hline & \multicolumn{3}{|c|}{ Male (4) } & \multicolumn{3}{|c|}{ Female (z) } \\
\hline \multirow[t]{4}{*}{ Control } & $38 \cdot 9$ & $53 \cdot 0$ & $46 \cdot I$ & $32 \cdot 0$ & $23 \cdot 8$ & $25 \cdot 2$ \\
\hline & $48 \cdot 6$ & $49^{\circ} 0$ & $45^{\circ} \mathrm{I}$ & $41 \cdot 6$ & $27 \cdot 0$ & $29^{*} 3$ \\
\hline & $40 * 4$ & $4 I \cdot 7$ & $49 \cdot 2$ & - & 一 & - \\
\hline & 40.9 & $43 \cdot 6$ & $45 \cdot 3$ & -- & - & - \\
\hline \multirow[t]{2}{*}{ Mean } & $42 \cdot 2$ & $46 \cdot 8$ & $46: 4$ & $36 \cdot 8$ & $25 \cdot 4$ & $27 \cdot 3$ \\
\hline & $176 \cdot 6$ & 195.8 & I $94^{\circ} \mathrm{I}$ & $154^{\circ} 0$ & $106 \cdot 3$ & I I $4 \cdot 2$ \\
\hline
\end{tabular}

for $\mathrm{C}$ groups $209 \pm 9^{\cdot} \mathrm{I} \mathrm{kcal}$. A consistency of intake was a prerequisite for meaningful comparisons between strains in respect of energy stored and energy output. The observed result therefore gave a satisfactory basis for interpretation of observations on the energy content of the carcass.

The energy contents of the carcasses of all the mice of a given strain and sex killed on day o, day 9 and day 18 are shown in Table 7 . As expected, the total energy of the carcasses was greater for the $\mathrm{L}$ mice than for the $\mathrm{C}$ mice. The fat comprised one-third to one-half of the total energy of the body, a slightly higher proportion in males than in females. During the $18 \mathrm{~d}$, both $\mathrm{L}$ and $\mathrm{C}$ male animals had increased the total energy content of the body. But whereas $\mathrm{L}$ males had retained on average $6.7 \mathrm{kcal}$, the $\mathrm{C}$ males, on the same energy intake, had retained only $4^{\cdot 2} \mathrm{kcal}$. In fernales of both strains there was a loss of total energy content over this period, although the metabolizable energy intake was about the same as that of the males.

\section{DISCUSSION}

The high rate of growth of $\mathrm{L}$ mice after weaning is remarkable and the differences between strains in final body-weight would seem to be largely established at this period of life. This phase of rapid growth has been noted also by Fowler (I962), who found that it was accompanied by an unusually high level of activity. The general similarity of the three strains in respect of body composition in early life is also in accord with the observations of Fowler (1958). The slight decrease in percentage of fat in the body between the ${ }_{1} 5^{\text {th }}$ and 20 th days is in line with observations made on young rats (Widdowson $\&$ McCance, Ig6o), whose carcass fat showed a similar decrease when the animal began to take food other than maternal milk.

Fowler (1958) reported significant differences in birth weight in strains of mice 
selected for body size. The differences recorded in this work are of similar order to those of Fowler, but less marked, as our S mice were on average slightly heavier at birth than hers. Differences in birth weight are determined not only by genetic makeup but also by prenatal environment, as Brumby (1960) has shown.

The different growth rates of the three genetic strains was already obvious during suckling. That this variation was associated with differences in appetite of the young mice is suggested by the fact that young $\mathrm{L}$ mice fostered by an $\mathrm{S}$ mother were able to grow more rapidly than young $\mathrm{S}$ mice would do. Indeed, since $\mathrm{S}$ mothers were able to support the same growth rate in a litter of eight as in a litter of four (Table 2), a limitation in the supply of milk could hardly have been the main cause of the slow growth of $S$ young.

However, milk supply probably contributed to the difference in growth rate between $\mathrm{L}$ and $\mathrm{C}$ mice during suckling. This is shown by a comparison of the amount of teduction in growth rate in natural-sized litters as compared with 'quads' in these two strains. 'Quad' litters of the two strains showed similar high growth rates, but whereas the $\mathrm{L}$ mothers, rearing their young in natural litters, could support a growth rate which was on avcrage nearly $75 \%$ of the rate of 'quad' litters, the $\mathrm{C}$ mothers with natural litters could support a growth rate which was on average only $55 \%$ of the rate achieved by 'quad' litters, a growth rate, in fact, which was no greater than that of $S$ mice. A possible interpretation of these results, taken together with those of the fostering experiment, is that any difference in growth rate between $\mathrm{S}$ and $\mathrm{C}$ mice was associated with the appetite of the young, whereas the difference between $\mathrm{C}$ and $\mathrm{L}$ mice was partly dependent on material milk supply.

Food intake after weaning increased as body-weight increased within each strain, and an apparently continuous intake-weight relation between strains is demonstrated in Fig. 3. This might suggest voluntary food intake as the primary characteristic which has been selected genetically, although this is not supported by the higher bodyweights maintained by the $\mathrm{L}$ mice in comparison with the $\mathrm{C}$ mice on a restricted feeding regimen in Expts 2, 3 and 4, in which L mice maintained a consistently higher body-weight than the $\mathrm{C}$ mice with the same intake. In consequence of the phase of rapid growth immediately after weaning, the increments of weight from the beginning of measurements were not so dissimilar between $L$ and $S$ mice as they would have been if measurements had begun at birth. It is possible that longer periods on equal restricted intakes begun after the phase of rapid growth might produce $\mathrm{L}$ and $\mathrm{C}$ mice of similar body-weight, although the present results do not suggest this.

The concept that level of food intake is necessarily primary is also not supported by results of the comparative slaughter in Expt 4, which indicate a tendency to higher retention for $\mathrm{L}$ mice than for $\mathrm{C}$ mice which have the same food intake (see Tables 5 and 6). In both $\mathrm{L}$ and $\mathrm{C}$ mice the females lost energy from the carcass, whereas the males, on average, gained energy during the same period. This finding suggests a higher level of activity in the females, possibly associated with the oestrous cycle. Determination of digestibility of the food showed the L, C and S mice all to be similar in this respect, and consequently it is unlikely that strain differences in gross efficiency are attributable to differences in digestibility of the food eaten. 
The technical assistance of M. Bacon and P. Hebblethwaite is gratefully acknowledged.

\section{REFERENCES}

Brumby, P. J. (I 960). Heredity, Lond. 14, I.

Falconer, D. S. (1960). Genet. Res. I, 9r.

Fowler, R. E. (1958). F. agric. Sci., Camb. 51, I37.

Fowler, R. E. (1962). Genet. Res. 3, 51 .

Herrington, L. P. (1940). Am. Y. Physiol. 129, I23.

Mount, L. E. (197I). F. Physiol., Lond. 217, $3 \times 5$.

Roberts, R. C. (1966). Genet. Res. 8, 347.

Widdowson, E. M. \& McCance, R. A. (I960). Proc. R. Soc. B 152, I88. 